einstein

Official Publication of the Instituto Israelita

de Ensino e Pesquisa Albert Einstein

ISSN: 1679-4508 | e-ISSN: 2317-6385
How to cite this article:

Fichman V, Costa RS, Miglioli TC,

Marinheiro LP. Association of obesity and anovulatory infertility. einstein (São Paulo). 2020;18:eA05150. http://dx.doi.org/10.31744/ einstein journal/2020A05150

Corresponding author: Váleria Fichman

Avenida Rui Barbosa, 716,

setor de ensino, $4^{\text {th }}$ floor - Flamengo

Zip code: 20021-140 - Rio de Janeiro, RJ, Brazil

Phone: (55 21) 2554-1833

E-mail: vfichman@gmail.com

Received on:

May 7, 2019

Accepted on:

Oct 3, 2019

Conflict of interest:

none.

Copyright 2020

(c) BY

This content is licensed

under a Creative Commons

Attribution 4.0 International License.
ORIGINAL ARTICLE

\section{Association of obesity and} anovulatory infertility

\section{Associação entre obesidade e infertilidade anovulatória} \author{
Lizanka Paola Figueiredo Marinheiro ${ }^{1}$ \\ 1 Fundação Oswaldo Cruz, Rio de Janeiro, RJ, Brazil. \\ 2 Universidade Iguaçu, Iguaçu, RJ, Brazil.
}

Valéria Fichman', Roseli de Souza Santos da Costa', Teresa Cristina Miglioli²,

DOI: 10.31744/einstein_journal/2020A05150

\section{ABSTRACT}

Objective: To verify the association of obesity and infertility related to anovulatory issues. Methods: This case-control study was carried out with 52 women, aged 20 to 38 years, divided into two groups (infertile - cases - and fertile - control), seen at outpatient clinics, in the period from April to December, 2017. Results: We found significant evidence that obesity negatively affects women's fertility $(p=0.017)$. The group of infertile women was 7.5 -fold more likely to be obese than fertile women. Conclusion: Strategies that encourage weight control are indicated for women with chronic anovulation, due to hight metabolic activity of adipose tissue.

Keywords: Infertility, female; Anovulatory; Obesity; Reproduction; Feeding behavior; Motor activity

\section{RESUMO}

Objetivo: Verificar em mulheres a associação entre obesidade e infertilidade relacionada a questões anovulatórias. Métodos: Estudo de caso-controle com 52 mulheres, de 20 a 38 anos, divididas em dois grupos (mulheres inférteis - casos - e férteis - controles), atendidas em ambulatórios, no período de abril a dezembro de 2017. Resultados: Verificou-se evidência significativa de que a obesidade afeta negativamente na fertilidade das mulheres $(p=0,017) .0$ grupo de mulheres inférteis teve 7,5 vezes mais chances de serem obesas quando comparadas às mulheres férteis. Conclusão: Estratégias que estimulem o controle do peso são indicadas para mulheres com anovulação crônica devido à elevada atividade metabólica do tecido adiposo.

Descritores: Infertilidade feminina; Anovulatória; Obesidade; Reprodução; Comportamento alimentar; Atividade motora

\section{INTRODUCTION}

Infertility is defined as the absence of pregnancy after one year of regular sexual intercourse without the use of contraceptives, for women under 35 years, and as of the sixth month of attempting to conceive for women 35 or more years of age. ${ }^{(1)}$ It is an ever more frequent phenomenon in developed societies and affects about 48.5 million couples around the world. ${ }^{(2)}$

Fertility can be negatively affected by various hypothalamic, pituitary, thyroid, adrenal, and ovarian disorders, as well as by the usage of drugs, advanced age, and obesity. ${ }^{(3)}$ Among the primary factors involved in infertility of couples, those related to female issues are classified as being tuboperitoneal and ovulatory. ${ }^{(4)}$ The latter are influenced by extremes of body weight, which contribute towards insulin resistance, ${ }^{(5)}$ reflected in anovulation. ${ }^{(6)}$ 
It is increasingly acknowledged that the obesity epidemic contributes towards fertility problems. ${ }^{(7)}$ According to information from the Pesquisa de Orçamentos Familiares [Family Budget Research], performed in Brazil between 2008 and 2009, among women aged 20 or more years, $48 \%$ were overweight (body mass index $/ \mathrm{BMI} \geq 25 \mathrm{~kg} / \mathrm{m}^{2}$ ) and $17 \%$ were obese $\left(\mathrm{BMI} \geq 30 \mathrm{~kg} / \mathrm{m}^{2}\right)$. This is a worldwide issue. ${ }^{(8)}$ Until now, there have been few observational studies about the association between obesity and infertility in the Brazilian population.

The lack of knowledge about infertility hinders the adoption of preventive measures in its treatment. ${ }^{(9)}$ Obesity, and primarily abdominal obesity, participates in this etiology, and the awareness of its relation with infertility is extremely important, so that the nutritional status of subfertile women, that is, women with absence of conception who actively want to conceive, can be corrected. ${ }^{(10)}$

Ovulatory defects and inexplicable causes represent more than $50 \%$ of etiology of infertility ${ }^{(11)}$ and, although not the only factors involved, one should carefully analyze the ovulatory issues with the intention of positive reversal for a fertility process.

Abdominal obesity, common in patients with polycystic ovary syndrome (PCOS), is involved in the secretion of various hormones and cytokines that contribute towards the start of a proinflammatory status and oxidative damage, ${ }^{(12)}$ negatively affecting the complex hormone environment, generating disorders in the hypothalamus-pituitary-ovarian axis ${ }^{(13)}$ and, consequently, acting in the deregulation of the menstrual cycle and in the reproductive capacity of the woman.

Polycystic ovary syndrome is a heterogeneous condition characterized by irregular ovulations or anovulation, hyperandrogenism, oligomenorrhea, and subfertility. ${ }^{(14)}$ Obesity occurs in $30 \%$ to $75 \%$ of women with PCOS, ${ }^{(15)}$ and increases the magnitude of hormone and metabolic dysfunction of these women. ${ }^{(14)}$

\section{OBJECTIVE}

To investigate the association of obesity and infertility related to anovulatory issues in women, and to identify associated factors.

\section{METHODS}

\section{Study population}

This is a case-control study conducted with women seen at outpatient clinics of the Instituto Nacional da Saúde da Mulher, Criança e do Adolescente Fernandes Figueiral Fundação Oswaldo Cruz (IFF/Fiocruz), in the city of Rio de Janeiro (State of Rio de Janeiro/RJ), between April and December 2017. Pairing of the sample was done by age.

As cases, women treated at the infertility outpatient clinic, with anovulatory problems defined by the physician in charge, were enrolled, and as controls, pregnant women seen at the prenatal outpatient clinic, who desired to participate in the study. In both groups, women under 20 years of age or over 38 years of age were excluded, in addition to those seen at the infertility outpatient clinic with tuboperitoneal problems or their partners' sperm issues.

The parameters used for the diagnosis of anovulatory issues included clinical history and determination of serum levels of follicle-stimulating hormone (FSH), luteinizing hormone (LH), estradiol and progesterone.

The sample was calculated considering the results of the infertility study, ${ }^{(16)}$ which observed the marker of oxidative stress in follicular fluid in infertile women (lipid peroxidase/LPO). In Group 1, women without PCOS, with abdominal obesity (a value of $1.0 \pm 0.3$ ) were enrolled, and for Group 2, women without PCOS and without abdominal obesity (a value of $0.79 \pm 0.2$ ).

The confidence interval adopted was $95 \%$ with a power of $80 \%$, generating a sample size of 24 observations in each group, totaling up 48. The sample was incremented only in the controls by $16 \%$ (4 cases), due to the fact of more patients not having been seen with anovulation at the infertility outpatient clinic during the chosen period for collection, totaling 52 participants in the study, classified as Case (24) and Control (28) Groups.

\section{Measurements and data analysis}

Data collection was performed using the International Physical Activity Questionnaire (IPAQ) and a previously tested questionnaire, prepared for the investigation, divided into three parts: the first contained questions related to sociodemographic information, such as age, occupation, district, and city of residence. The second part contained information on the clinical history, such as diabetes mellitus, hypertension, PCOS, other diseases, as well as the habit of smoking and using alcoholic beverages. The use of alcoholic beverages was classified as 1 - does not use / 2 - uses once in a while / 3 - uses daily / 4 - uses on weekends.

In the third part, the anthropometric values of weight, height, abdominal circumference (AC), and hip circumference (HC) were described. The BMI was 
categorized as 1 - low weight: $<18.5 \mathrm{~kg} / \mathrm{m}^{2} ; 2$ - adequate: 18.5 to $24.9 \mathrm{~kg} / \mathrm{m}^{2} ; 3$ - overweight: 25.0 to $29.9 \mathrm{~kg} / \mathrm{m}^{2} ; 4$ obesity: $\geq 30.0 \mathrm{~kg} / \mathrm{m}^{2}$.

The predictive variables analyzed in this study were BMI, physical activity, and alcohol and smoking habits. The remaining variables cited above, such as AC, $\mathrm{HC}$, diabetes mellitus, hypertension, and PCOS were included in the study but were not analyzed between the two groups.

The BMI was calculated for each woman, by means of the weight/height squared ratio, and was classified as per the criteria of the World Health Organization (WHO), 2000 (https://www.who.int/nutrition/publications/ obesity/WHO_TRS_894/en/).

The anthropometric measurements of weight, height, $\mathrm{AC}$, and $\mathrm{HC}$ of the cases were checked on the days patients were seen at the infertility outpatient clinic, and the anthropometric measurements of weight and height were obtained from pregestational reports of weight and height from the controls at the time of the interviews. For pregnant women who did not know their height, it was measured at the time of the interview.

The AC of the cases was measured around the region of the greatest diameter, normally coinciding with the umbilical scar. ${ }^{(17)}$

The AC and $\mathrm{HC}$ variables were not evaluated for the Control Group, due to the anatomical modification related to pregnancy.

The variables of use of alcohol, smoking, and physical activity were collected by self-reports and checked relative to the pregestational period in the Control Group, and relative to the current period for the Case Group. The condition of having diabetes mellitus, hypertension, and PCOS was only checked in the Case Group.

The IPAQ was proposed by WHO in 1998 and was validated in Brazil by means of a pilot study in Brazilian young adults. ${ }^{(18)}$ We used the short version, which covers the types of physical activity that people do in their daily living, as part of a large study divided among different countries.

The data was analyzed based on frequency (categorical variables), mean, and standard deviation (numerical variables).

For comparison between the groups, the $\chi^{2}$ and Fisher's exact tests were used, carried out with (SPSS) software, version 22.

\section{Ethical considerations}

All the participants signed the Informed Consent Form (ICF). The research project was approved by the Committee of Ethics and Research in Human Beings
(CEPIFF), under opinion number 2.374.634, CAAE: 63617616.6.0000.5269, submitted on February 15, 2017.

\section{| RESULTS}

The mean age of the infertile women observed was 31 years, and of fertile women, 27 years.

The hypothesis test of the women seen at the infertility and prenatal outpatient clinics of IFF/Fiocruz by means of the variable BMI, presented with statistical evidence $(p<0.05)$ that obesity interfered in fertility of women. Table 1 shows the distribution of cases and controls, according to the variables studied.

Of all the variables with $\mathrm{p}<0.05$ that were entered into the multivariate model, only BMI demonstrated significance; the Case Group was 7.5-fold more likely to be obese when compared to the fertile women (Table 2).

Table 1. Comparison of the characteristics of women of two groups studied

\begin{tabular}{lccc}
\hline Patients & $\begin{array}{c}\text { Case Group } \\
(\mathbf{n = 2 4 )} \\
\text { \% }\end{array}$ & $\begin{array}{c}\text { Control Group } \\
(\mathbf{n = 2 8 )} \\
\%\end{array}$ & p value \\
\hline BMl & 17 & 54 & 0.017 \\
Low weight and eutrophy & 33 & 25 & \\
Overweight & 50 & 21 & 0.615 \\
Obesity & & & \\
Uses alcoholic beverages & 96 & 89 & 0.115 \\
No/once in a while & 4 & 11 & \\
DailyMeekends & & 86 & 1.000 \\
Smoking & 100 & 14 & \\
No & 0 & & \\
Yes & & 61 & \\
Physical activity & 58 & 39 & \\
Very active/active & 42 & & \\
Irregularly active/sedentary & & & \\
\hline Results expressed as \%. BMl: body mass index. & & & \\
\hline
\end{tabular}

Results expressed as \%. BMl: body mass index.

Table 2. Odds ratio for cases and controls, as per body mass index

\begin{tabular}{lc}
\hline BMI & Odds ratio \\
\hline Low weight and eutrophy & - \\
Overweight & $1.75(0.43-7.2)$ \\
Obesity & $7.5(1.72-32.8)$ \\
\hline
\end{tabular}

BMl: body mass index.

As to being a smoker, the comparison between the groups was close to statistical significance $(p=0.115)$, although no infertile patient smoked, and only four women from the prenatal outpatient clinic smoked $(14 \%)$. As to alcoholic beverages, in both groups, the majority of women did not consume them; no woman in the Case Group used alcohol daily, and only two fertile patients $(7 \%)$ consumed alcoholic beverages every day. 
Active and irregularly active women were the majority in both groups studied.

Abdominal obesity was noted in 21 infertile patients (87.5\%), indicating an increased risk of metabolic complications in these patients (Table 3 ).

Of the infertile patients, only one reported being diabetic (4.2\%), and two (8.3\%) were hypertensive.

Table 3. Risk of metabolic complications in the cases

\begin{tabular}{ll}
\hline Cut-off point/classification & \\
\hline$A C<80 \mathrm{~cm} /$ no risk & 12.5 \\
$A C \geq 80 \mathrm{~cm} /$ with increased risk & 87.5 \\
\hline
\end{tabular}

Results expressed as \%. AC: abdominal circumference.

\section{DISCUSSION}

This study investigated the association between obesity and infertility, two prevalent issues in modern female life, according to other findings already described in literature..$^{(5,7,8,14,16)}$ Knowledge about the association between obesity and infertility is important to deepen understanding of the factors that involve the worldwide obesity pandemic ${ }^{(19)}$ and comprehend it in addition to chronic noncommunicable diseases.

Most of the women with excessive weight, that is, overweight or obesity, were in the Case Group. Observing 1,880 women seen at infertility clinics in the United States and Canada, a study concluded that the relative risk of anovulatory infertility is 3.1 times greater in obese women. ${ }^{(20)}$ The relation between weight loss and improvement of the reproductive function is well established, but the mechanisms that act in optimizing this function need to be better clarified. ${ }^{(21)}$

It is important to point out there are several factors that influence the anovulation process, and these often occur concomitantly: oxidative stress, which can affect the follicular fluid, ${ }^{(16)}$ and modifications in the metabolism of sex hormones ${ }^{(22)}$ and insulin resistance. ${ }^{(23)}$

Obese women may present with damaged or decreased tolerance to glucose without being carriers of diabetes mellitus, since there is an intermediate stage between the homeostasis of glucose and diabetes. ${ }^{(24)}$ Half of the cases studied presented with obesity, and $95.8 \%$ of these patients did not suffer from diabetes mellitus, suggesting that they could be in this deficient glucose tolerance stage.

As to the use of alcoholic beverages and smoking, these findings were different relative to those of other studies, ${ }^{(3,9,25)}$ that observed an interference of these factors in the female reproductive capacity, since they cause modification in the hormone levels and decrease libido.

As to hypertension, $91.7 \%$ of cases studied reported not having this disease. Despite the fact that obesity is related to several comorbidities, such as hypertension, diabetes mellitus type 2, and some kinds of cancer and dyslipidemia, ${ }^{(26)}$ there are obese patients that present with only one or none of these comorbidities. This does not mean that there are cases of healthy obesity, since the inflammatory process is inherent to this disease, causing various damages to the health of patients.

The result of physical activity, with few sedentary women (none in the Case Group and four - 14\% in Control Group), could be related to the manner in which the IPAQ classified the moderate activities, including domestic activities that moderately increase breathing rate or heart beats and were very often included by the participants of this study as the only physical activity reported. The potential of the present study was to demonstrate that population studies follow the same pattern found in studies carried out in other countries, ${ }^{(7,11)}$ reinforcing the hypothesis that obesity interferes in infertility.

\section{CONCLUSION}

Obesity influences infertility, that is, there is a positive correlation between obesity and infertility. Knowledge of such a relation is important in order to increase the chances of subfertile women of reversing the situation of infertility, and having a healthy pregnancy. Improving eating habits and engagement in physical exercises are important to promote changes in body composition and nutritional status of these women.

The best management of women with chronic anovulation should be the development of strategies that stimulate weight control, before beginning a treatment cycle for assisted reproduction.

We suggest hospitals providing treatment for infertility offer nutritional care and encourage the practice of physical exercise to the population seen.

\section{ACKNOWLEDGEMENTS}

We Instituto Nacional da Saúde da Mulher, da Criança e do Adolescente Fernandes Figueira/Fundação Oswaldo Cruz, for accepting the development of this investigation; Dra. Lizanka Paola Figueiredo Marinheiro, for the reception at the endocrinology clinic; Dra. Roseli de S. Santos da Costa, for reception in the prenatal outpatient clinic; te Coordenação de Aperfeiçoamento de Pessoal de Nível 
Superior (CAPES), for the financial, number 1605128, support given throughout the Master's degree course; and the Graduation Course in Women, Children and Adolescents Health from IFF/Fiocruz, for the support throughout the investigation.

\section{AUTHORS' INFORMATION}

Fichman V: http://orcid.org/0000-0002-5792-1842

Costa RS: http://orcid.org/0000-0001-5671-828X

Miglioli TC: http://orcid.org/0000-0002-6718-652X

Marinheiro LP: http://orcid.org/0000-0001-6319-3338

\section{REFERENCES}

1. Practice Committee of American Society for Reproductive Medicine. Definitions of infertility and recurrent pregnancy loss: a committe opinion. Fertil Steril. 2013;99(1):63.

2. World Health Organization (WHO). Sexual and reproductive health. National, regional, and global trends in infertility: a systematic analysis of 277 health surveys [Internet]. Geneva: WHO; 2012 [cited 2019 May 17]. Available from: http://www.who.int/reproductivehealth/publications/infertility/277surveys/en/

3. Weiss RV, Clapauch R. Female infertility of endocrine origin. Arq Bras Endocrinol Metab. 2014;58(2):144-52. Review.

4. Speroff L, Fritz MA. Clinical Gynecologic Endocrinology and Infertility. 7th ed. Philadelphia: Lippincott Williams \& Wilkins; 2010

5. Reyes-Muñoz E, Ortega-González C, Martínez-Cruz N, Arce-Sánchez L, Estrada-Gutierrez G, Moran C, et al. Association of obesity and overweight with the prevalence of insulin resistance, pre-diabetes and clinicalbiochemical characteristics among infertile Mexican women with polycystic ovary syndrome: a cross-sectional study. BMJ Open. 2016;6(7):e012107.

6. Jarrett BY, Lujan ME. Impact of hypocaloric dietary intervention on ovulation in obese women with PCOS. Reproduction. 2016. pii: REP-16-0385.

7. Pandey S, Pandey S, Maheshwari A, Bhattacharya S. The impact of female obesity on the outcome of fertility treatment. J Hum Reprod Sci. 2010; 3(2):62-7.

8. Lim SS, Norman RJ, Davies MJ, Moran LJ. The effect of obesity on polycystic ovary syndrome: a systematic review and meta-analysis. Obes Rev. 2013; 14(2):95-109. Review.

9. Guimarães MM, Alexandre AE, Ribeiro JC. Prevalência e práticas preventivas em infertilidade entre mulheres atendidas em um serviço público de saúde. Reprod Clim. 2013;28(2):57-60.

10. Campanhol CL, Heinrich JK, Couto E, Barini R. Fenótipo de subfertilidade, polimorfismos cromossômicos e falhas de concepção. Rev Bras Ginecol Obstet. 2011;33(5):246-51.
11. Talmor A, Dumphy B. Female obesity and infertility. Best Pract Res Clin Obstet Gynaecol. 2015;29(4):498-506. Review.

12. Lear SA, James PT, Ko GT, Kumanyika S. Appropriateness of waist circumference and waist-to- hip ratio cutoffs for different ethnic groups. Eur J Clin Nutr. 2010;64(1):42-61. Review.

13. Gaspar RS, Benevides RO, Fontelles JL, Vale CC, França LM, Barros Pde T, et al. Reproductive alterations in hyperinsulinemic but normoandrogenic MSG obese female rats. J Endocrinol. 2016;229(2):61-72.

14. Diamanti-Kandarakis E. Role of obesity and adiposity in polycystic ovary syndrome. Int J Obes (Lond). 2007;31(Suppl 2):S8-13; discussion S31-2. Review.

15. Ehrmann DA. Polycystic ovary syndrome. N Engl J Med. 2005;352(12):1223-36. Review.

16. Nasiri N, Moini A, Eftekhari-Yazdi P, Karimian L, Salman-Yazdi R, Zolfaghari Z, et al. Abdominal obesity can induce both systemic and folicular fluid oxidative stress independente from polycystic ovary syndrome. EJOG. 2015;184:112-6.

17. Reis NT, Calixto-Lima L. Nutrição clínica: bases para prescrição. Rio de Janeiro: Rubio; 2014

18. Pardini R, Matsudo S, Araújo T, Matsudo V, Andrade E, Braggion G, et al. Validação do questionário internacional do nível de atividade física (IPAO versão 6): estudo piloto em adultos jovens brasileiros. Rev Bras Cien e Mov. 2001:9(3):45-51.

19. Hammond RA, Levine R. The economic impact of obesity in the United States. Diabetes Metab Syndr Obes. 2010;3:285-95.

20. Grodstein F, Goldman MB, Cramer DW. Body mass index and ovulatory infertility. Epidemiology. 1994;5(2):247-50.

21. Milone M, De Placido G, Musella M, Sosa Fernandez LM, Sosa Fernandez LV, Campana $\mathrm{G}$, et al. Incidence of sucessful pregnancy after weight loss interventions in infertile women: a systematic review and meta-analysis of the literature. Obes Surg. 2016;26(2):443-51. Review.

22. Bastard JP, Maachi M, Lagathu C, Kim MJ, Caron M, Vidal H, et al. Recent advances in the relationship between obesity, inflammation, and insulin resistance. Eur Cytokine Netw. 2006;17(1):4-12. Review.

23. Provost MP, Acharya KS, Acharya CR, Yeh JS, Steward RG, Eaton JL, et al. Pregnancy outcomes decline with increasing body mass index: analysis of 239.127 fresh autologous in vitro fertilization cycles from the 20082010 Society for Assisted Reproductive Technology registry. Fertil Steril. 2016;105(3):663-9.

24. Expert Committee on the Diagnosis and Classification of Diabetes Mellitus. Report of the expert committee on the diagnosis and classification of diabetes mellitus. Diabetes Care. 2003;26(Suppl 1):s5-s20.

25. Ramlau-Hansen $\mathrm{CH}$, Thulstrup AM, Nohr EA, Bonde JP, Sørensen TI, Olsen J. Subfecundity in overweight and obese couples. Hum Reprod. 2007; 22(6):1634-7.

26. Mariath AB, Grillo LP, Silva R0, Schmitz P, Kruger RM, Medina JR, et al Obesidade e fatores de risco para o desenvolvimento de doenças crônicas não transmissíveis entre usuários de unidade de alimentação e nutrição. Cad Saude Publica. 2007;23(4):897-905. 